\title{
Comprehension of Spatial Nouns Using a Locative Case Marker in Korean Preschool Children with Specific Language Impairment
}

\author{
Sungyi Choi ${ }^{\mathrm{a}}$, Hee Ran Lee ${ }^{\mathrm{b}}$ \\ ${ }^{a}$ Department of Speech and Hearing Therapy, Graduate School of Catholic University of Pusan, Busan, Korea \\ ${ }^{b}$ Department of Speech and Hearing Therapy, Catholic University of Pusan, Busan, Korea
}

Correspondence: Hee Ran Lee, PhD Department of Speech and Hearing Therapy, Catholic University of Pusan, 57 Oryundae-ro, Geumjeong-gu, Busan 46252, Korea

Tel: $+82-51-510-0841$

Fax: +82-51-510-0848

E-mail: hrlee@cup.ac.kr

Received: October 3, 2019

Revised: November 10, 2019

Accepted: November 12, 2019

\begin{abstract}
Objectives: The purpose of this study was to investigate the effects of morphosyntactic cues using a locative case marker to infer the meaning of spatial nouns for Korean preschool children with specific language impairment (SLI). Methods: Participants included $15 \mathrm{SLI}$ children, aged 5 to 6 years, who were compared to 15 typically developing (TD) children matched for age. This study examined the ability of comprehension of spatial nouns using the case marker '-ey' in two groups of children through a simple composition task and a multiple composition task. Results: In the simple composition task, the group of children with SLI could choose the appropriate spatial relationship scene as well as the TD group. However, in the multiple composition task, the SLI group showed lower performance than the TD group. Conclusion: The SLI group was more difficult than TD group to interpret the meaning of new nouns into spatial nouns with cue to'-ey' in the complex multiple composition task. In this study, we interpreted the limitations of fast mapping the difficulty of understanding spatial nouns in children with SLI, the difficulties of morphological syntactic bootstrapping, and related factors. In conclusion, this study suggests that for children with $\mathrm{SLI}$, an effective vocabulary intervention is required. This involves a clinical intervention focusing on syntactic aspects, such as grammatical morphemes, sentence structure, as well as focusing on the meaning of words.
\end{abstract}

Keywords: Spatial nouns, Specific language impairment (SLI), Morphosyntactic bootstrapping 공간(space)은 어떠한 행위가 이루어지는 가장 기본적인 환경이 다. 우리는 공간에 속에 있는 대상의 형태나 위치, 움직임을 보고 듣 고 만져 보며 인식할 수 있다. 아동의 초기 발달 과정에서 공간적 특 성을 이해하는 능력은 이를 나타내는 어휘의 습득과 함께 아동의 인지 발달 정도를 평가하는 중요한 측정치로 기능할 수 있다. 공간 어(spatial term)는 물리적 대상의 공간적 특성이나 위치 변동에 대 한 용어를 일컫는다(Zlatev, 2010). 공간어는 문법적 성질에 따라 품 사별로 분류할 수 있다. $\operatorname{Min}$ (1999)은 공간어 범주를 공간명사, 공 간대명사, 공간수사, 공간동사, 공간관형사, 공간부사 등으로 나누 었다. 그 중 공간명사(spatial noun)는 '앞, 뒤, 위, 아래, 오른쪽, 왼 쪽, 옆, 곁...' 등의 사물의 형태적 공간성 및 사물의 특정 부분을 가
리키는 용어로 공간적 위치와 방향을 나타내는 처소격조사 '-에', ‘-에서', ‘로' 등과 함께 사용된다. 그리고 공간명사는 공간의 의미 를 토대로 하여 시간이나 상황, 원인, 목적 등을 개념화하고 기술하 는 데 자연스럽게 사용된다.

초기 언어와 인지 발달에서의 중요성을 감안하여 공간 개념 발 달에 관련된 연구들이 꾸준히 행해지고 있다. 예를 들어, 생후 3 개 월 밖에 되지 않은 영아들도 친숙한 사물들 간의 위, 아래, 왼쪽, 오 른쪽 등의 공간 관계를 구분할 수 있다(Quinn, 2005). 그러다 6개월 이 되면서 친숙하지 않은 사물들이 이루는 공간 관계를 구분할 수 있고 포함(containment), 위(above), 아래(below)에 대한 추상적인 공간 범주를 형성하기 시작한다(Quinn, 2005). 이와 더불어, Clark 
(1980)은 아동이 2세에서 2세 5개월에 이르면 처음으로 전치사 'in' 과 이와 더불어 'on'을 사용하여 위치나 공간 개념을 표현할 수 있 음을 제안하였다. 그리고 1 세 6 개월에서 5 세 아동을 대상으로 이루 어진 사물의 위치에 대한 실험 결과, 아동은 연령이 증가할수록 위 치 구별을 더 잘하였고 공간명사 중 ‘위’와 ‘아래’가 먼저 발달하였 으며 후에 '앞'과 ‘뒤'가 발달한 것으로 나타났다. 국내 선행연구들 간에 공간명사의 발달 순서에는 약간의 차이를 보이기는 하나 '위', ‘아래', '앞', ‘뒤'의 공간명사가 일찍 습득된다는 결과는 일치하는 것 으로 볼수 있다(Korea Institute for Research in the Behavioral Sciences [KIRBS], 1980; Lee, 1990; Yoon, 1985). 이러한 선행연구들의 결과를 고려해 볼 때 5-6세 아동에게 '위', '아래', '앞', '뒤'의 네 가지 명사는 공간명사의 발달을 확인하는 중요한 측정치로 작용한다고 볼수 있다.

Clark (1973)은 아동이 1세 6개월경에 이미 공간 관계의 개념들 을 온전히 획득하고 있음을 입증하고, 이러한 인지적인 지식이 언 어의 장소격 전치사로 사용되고 있다고 하였다. 또한 실제로 영어 를 사용하는 아동이 가장 먼저 산출하는 전치사가 'in'과 'on'이며, 이는 2세에서 2세 6개월 사이에 관찰된다고 하였다. Lee와 Lee (2012) 에 따르면 주격조사와 비슷하게 아주 일찍부터 사용하기 시작하는 조사가 처소격조사이며 아동이 2세에 접어들면서 처소격조사를 능숙하게 사용할 수 있다고 하였다. 또한 Yi (2000)는 격조사 중 ‘-에'와 같은 처소격조사는 비교적 쉽게 획득하여 30 개월 영아의 $67.6 \%, 36$ 개월 영아의 $86.7 \%, 42$ 개월 영아의 $90.6 \%, 48$ 개월 영아 96.9\%가 획득했다고 보고하였다. 따라서 처소격조사 '-에'는 아동 의 언어 발달 단계의 초기에 나타나며, 사용 빈도가 높은 중요한 문 법형태소라고 할 수 있다.

아동은 발달 과정에서 여러 경로를 통해 새로운 단어를 끊임없 이 배워 나간다. 이 과정에서 발화 내용이 더해지고 의미관계가 복 잡해질수록 격조사나 보조사와 같은 문법형태소는 문장의 표현과 이해에 중요한 역할을 한다. 무엇보다 격조사는 체언에 붙어 문장 내의 다른 말과의 관계를 분명히 드러내주어 의미 이해를 돕기도 한다. 학령전 아동은 새로운 어휘를 아주 빠른 속도로 습득해 나가 는데, 이때 빠른연결하기(fast-mapping) 책략을 사용한다. 빠른연 결하기는 아동이 새로운 어휘에 대한 최소한의 노출만으로도 그 어휘가 어떠한 참조물을 지칭하는지를 빠르고 정확하게 찾아내어 학습하는 전략이다(Carey, 2010).

아동이 명사, 동사, 형용사를 구별할 정도로 문법을 알게 되면 그 들은 단어 의미를 알아내는 단서로 문법을 사용할 수 있게 된다 (Hoff, 2009). 아동은 이러한 언어에 대한 지식을 바탕으로 자동처 리(bootstrapping) 과정을 통해 자기가 모르는 언어 정보를 해석한
다. 자동처리는 한 영역의 지식을 사용하여 다른 영역에서의 수행 을 증진시키는 것이다(Owens, 2012). 예를 들어, 문장의 주어나 서 술어 의미를 바탕으로 문장의 의미를 해석하거나 맥락과 문장구성 을 활용하여 단어의 의미를 알아낸다. 또한 문장구조에 나타나는 조사, 명사의 수, 그리고 명사의 배열과 같은 형태통사적 정보를 동 사 의미 이해에 도움을 주는 단서로 활용하여 동사 습득을 촉진할 수 있으며, 이를 형태통사적 자동처리(morphosyntactic bootstrapping)라고 한다(Göksun, Küntay, \& Naigles, 2008).

영어를 모국어로 사용하는 아동들은 문장 내의 명사의 수를 단 서로 하여 동사의 의미를 해석해 나가는 전략을 사용하기도 한다 (Fisher, 2002). 국내 연구에서도 아동들이 격조사와 같은 형태론적 정보를 활용하여 새로운 단어의 의미를 해석할 수 있었다. Lee와 Song (2009)의 연구에서는 2 세 5 개월의 한국아동들이 주격 또는 목적격조사와 같은 형태소 정보를 활용하여 새로운 동사의 의미를 이해할 수 있었다. 그리고 3-4세의 한국아동들은 주격조사 '-가' 와 처소격조사'-에'가 수반된 명사의 의미를 다르게 해석할 수 있었다 (Lee \& Song, 2010a). 또한 5세 이상의 아동들이 추상적인 '위', ‘아 래', '안'과 같은 사물들 간의 공간 관계를 지시하는 새로운 명사 학 습에 있어서 처소격조사를 활용할 수 있음을 보여주었다(Lee \& Song, 2010b). 이와 같은 연구결과들은 아동이 새로운 단어가 포함 된 문장을 이해하는 과정에서 문법형태소가 중요한 단서로 작용할 수 있다는 형태통사적 자동처리 가설을 뒷받침한다.

문장을 이해하기 위해서는 사용된 단어와 맥락을 이해는 동시 에 각각의 단어들이 다른 단어와 어떻게 결합되고, 서로 어떠한 관 련성이 있는가를 분석하는 문장구조에 대한 이해가 필수적이다. 하지만 단순언어장애 아동은 일반아동보다 문장 내 통사정보를 이 해하는 능력에 결함을 나타낸다(Kim, Jang, \& Kim, 2011). 단순언 어장애(specific language impairment, SLI) 아동은 인지, 감각 및 기타 신경학적 질환이 없음에도 언어 발달과 습득에서 지체나 결 함을 보인다(Leonard, 2014). 많은 선행연구에서는 단순언어장애 아동들이 새로운 어휘를 습득하는 과정에서 빠른연결하기에 어려 움을 가진다고 보고하였다(Dollaghan, 1987; Ellis Weismer \& Hesketh, 1998; Gray, 2003; Nash \& Donaldson, 2005; Rice, Oetting, Marquis, Bode, \& Pae, 1994). 또한 단순언어장애 아동의 전치사 (prepositions) 이해 특성을 살펴본 국외연구에서는 이들이 공간을 나타내는 전치사 'in'과 'on'의 통사론적 기능을 이해하지만, 이러 한 전치사의 의미 이해에 있어서는 일반아동보다 어려움을 보인다 고 하였다(Grela, Rashiti, \& Soares, 2004). 이와 같이 단순언어장애 아동은 어휘 습득 능력과 통사론 영역에서 특징적인 결함을 가지 고 있다. 
한국어를 습득하는 아동들에게는 초기 단어 조합 단계에서부 터 문법형태소가 새로운 어휘 습득에 결정적인 역할을 하기 시작 한다. 어순이 고정적인 영어와는 달리 한국어의 경우 초기 어순은 고정되어 있으나 문법형태소를 획득한 이후에는 초기의 고정된 어 순에서 어느 정도 자유로워 진다는 특징이 있다(Zoh, 1982). 한국 어의 또 다른 특징 중 하나는 문장에서 주어와 목적어의 문장성분 생략이 허용된다는 것이다. 이 경우 문장의 의미를 이해하기 위해 서 문법형태소의 역할이 더욱 강조된다. 다시 말해 문법형태소는 한 국아동의 언어 발달 과정에서 습득해야할 중요한 발달과업이다.

문법형태소 중 특히 공간의 특성을 내포한 처소격조사 '-에’는 아 동기 초기에 빠르게 발달하며 이와 더불어 공간을 표현하는 언어 발달도 심 없이 이어진다. 아동은 일상 속에서 다양한 공간 관계를 경험하면서 공간과 관련된 정보를 듣고 이해하거나 표현하게 된다. 이러한 경험은 아동이 5-6세로 접어들면서 점차 잦아지게 되고 그 에 따라 공간과 관련된 언어표현이 능숙해지게 된다. 동시에 아동 은 사물의 위치, 방향과 같은 공간 정보를 타인과 보다 자세하게 주 고받기 시작하는데, 이때 언어는 공간에 대한 정보를 소통하기 위 한 중요한 수단으로 사용된다. 따라서 학령전 시기 아동에게 문법 형태소를 활용한 공간명사의 습득은 이들의 언어와 인지 발달 정 도를 가늠하는 중요한 발달 요인으로 작용한다. 더 나아가 추후 학 령기에 접어들어 자신이 살아가는 공간과 장소, 주변 세계에 대한 인지, 그 이상의 자주적 의사결정 능력을 발달시키는 데 있어서도 공간 지식을 이용한 의사소통 능력은 중요하다. 그러므로, 인지 능 력과는 달리 언어 습득에만 어려움이 있는 단순언어장애 아동에 게서 이러한 문법형태소를 활용한 공간명사 습득 과정은 이들의 발달적 특성을 살펴볼 수 있는 매우 의미 있는 임상적 시사점을 제 공해줄수 있을 것으로 보여진다.

이에 본 연구에서는 단순언어장애 아동이 새로운 공간명사 뒤에 처소격조사 '-에'가 위치한 문장을 듣고 이를 단서로 하여 적절한 공간명사로 이해할 수 있는 지를 과제에서 제시되는 사물의 수를 달리한 단순구성 과제와 다중구성 과제를 통하여 생활연령을 일 치시킨 일반아동과 비교하였다. 따라서 본 연구의 연구문제는 다 음과같다.

(1) 집단(단순언어장애, 일반) 간 단순구성 과제에서 정반응 점수 에 차이가 있는가?

(2) 집단(단순언어장애, 일반) 간 다중구성 과제에서 같은 공간 관계 장면을 선택한 비율에 차이가 있는가?

(3) 각 집단(단순언어장애, 일반) 내 다중구성 과제에서 선택한 장면(같은 공간장면, 같은 사물장면)의 비율에 차이가 있는가?

\section{연구방법}

\section{연구대상}

본 연구는 생활연령이 5-6세인 단순언어장애 아동 15 명과 이들 과 생활연령을 \pm 3 개월 범위 내로 일치시킨 일반아동 15 명, 총 30 명을 대상으로 실시하였다.

단순언어장애 아동 집단은 Leonard (2014)의 진단 기준을 참조 하여 다음과 같이 선정하였다. (1) 취학전 아동의 수용언어 및 표현 언어척도(Preschool Receptive-Expressive Language Scale, PRES; $\mathrm{Kim}$, Sung, \& Lee, 2003) 검사 결과, 수용언어와 표현언어 모두 백 분위 점수 $10 \%$ ile 이하에 속하고, (2) 아동용 웩슬러 유아지능검사 (Korean-Wechsler Preschool and Primary Scale of Intelligence, KWPPSI; Park, Kwak, \& Park, 1997) 결과, 동작성 지능이 85 이상이 고, (3) 부모나 유치원 교사 보고에서 시각과 청각, 기타 신경학적 질 환, 구강구조와 기능의 이상, 사회적 상호작용의 능력에 심각한 결 함이 없으며, (4) 언어재활사에 의해 단순언어장애로 진단받은 아 동으로 선정하였다.

일반아동 집단은 (1) 취학전 아동의 수용언어 및 표현언어검사 결과, 수용언어와 표현언어 모두 백분위 점수 $16 \% \mathrm{ile}$ 이상에 속하 고, (2) 아동용 웩슬러 유아지능검사 결과, 동작성 지능이 85 이상 이며, (3) 부모나 유치원 교사 보고로 인지, 신체, 언어 발달이 정상 이면서 시각과 청각 기타 신경학적 문제가 없는 것으로 보고된 아 동 중 (4) 단순언어장애 아동과 일대일로 대응했을 때 생활연령이 \pm 3 개월 이내인 아동으로 선정하였다.

두 집단 사이에 연령 통제가 잘 이루어졌는지 확인하기 위해 독 립표본 $t$-검정을 실시하였다. 그 결과, 단순언어장애 아동 집단과 일 반아동 집단 간 생활연령에 따른 유의미한 차이는 없는 것으로 나 타났다 $(t=-1.890, p>.05)$. 그리고 두 집단 간 동작성 지능의 차이가 통계적으로 유의미한지 독립표본 $t$-검정을 실시한 결과, 유의미한 차이가 없었다 $(t=-.200, p>.05)$. 취학전 아동의 수용언어 및 표현 언어 검사 결과, 수용언어 백분위 점수에서 두 집단 간 유의미한 차 이가 나타났다 $(t=-10.236, p>.05)$. 그리고 표현언어 백분위 점수에 서도 유의미한 차이가 나타났다 $(t=-6.274, p>.05)$. 독립표본 $t$-검 정 결과는 Table 1 에 제시하였다.

\section{연구도구 및 절차}

본 연구에서 단순언어장애 아동이 조사 ‘-에’를 형태통사적 단서 로 활용하여 새로운 낱말을 공간명사로 이해할 수 있는지를 살펴 보기 위해 과제에서 제시되는 사물의 수를 달리한 단순구성 과제 와 다중구성 과제를 구성하였다. 이 두 가지 과제는 '안(in)', '위(on)', 
Table 1. Participants' characteristics

\begin{tabular}{lccc}
\hline Characteristic & SLI group (N=15) & TD group (N=15) & $t$ \\
\hline Age (mo) & $67.47(6.94)$ & $67.93(5.76)$ & -1.890 \\
Nonverbal IO ${ }^{\text {a }}$ & $96.47(7.39)$ & $102.13(8.95)$ & -.200 \\
PRES (\%ile score) & & & \\
Receptive language & $5.93(2.94)$ & $67.80(23.22)$ & $-10.236^{*}$ \\
Expressive language & $3.20(1.94)$ & $46.87(26.89)$ & $-6.274^{*}$ \\
\hline
\end{tabular}

Values are presented as mean (SD).

$S L I=$ children with specific language impairment; $T D=$ children with typically developing; PRES=Preschool Receptive-Expressive Language Scale (Kim, Sung, \& Lee, 2003).

aKorean-Wechsler Preschool and Primary Scale of Intelligence (Park, Kwak, \& Park, 1997).

${ }^{*} p<.05$

'아래(under)'와 같은 전치사가 사물들 간의 공간 관계를 명명하는 언어적 특성에 근거하여 이들 세 가지 공간 관계를 중심으로 구성 된 Lee와 Song (2010b)의 과제를 수정하고 보완하여 재구성하였다.

국내 선행연구들에서는 공간명사 중 ‘위’, ‘아래’, ‘앞', ‘뒤’ 가 비교 적 빠르게 습득된다고 알려져 있다(KIRBS, 1980; Lee, 1990; Yoon, 1985). 이를 반영하여 본 연구에서는 ‘위', ‘아래', ‘앞', ‘뒤’의 네 가지 공간 관계를 중심으로 과제를 구성하였다.

\section{단순구성 과제}

단순구성 과제에는 아동이 사물들이 특정한 공간 관계를 이루 고 있는 장면과 검사자가 들려주는 '가더에 있어.', '가더에 없어.'와 같은 문장을 듣고 새로운 명사(예: 가더)를 적절한 ‘위', ‘아래'와 같 은 공간명사로 이해할 수 있는지를 구문이해 및 형태통사적 자동 처리 능력에 초점을 두어 살펴보고자 하였다. 과제는 총 세 단계로, 아동의 적절한 반응을 돕기 위해 각 문항에서 사용되는 사물 그림 을 소개하는 친숙화단계, 긍정예시와 부정예시를 제시하는 대비단 계, 사전 단계들을 통해 아동의 반응을 유도하는 검사단계로 구성 하였다. 검사자는 각 단계를 순차적으로 진행하였다. 두 집단의 아 동이 친숙화단계와 긍정예시에서 제시된 사물들이 이루고 있는 공 간 장면과 동일한 장면을 검사단계에서 선택할 수 있는지를 정반 응 점수를 통해 알아보았다.

이에 따라 각 문항에서 위치가 유동적인 대상사물 1 개(예: 책)와 위치가 고정되어 있고 대상사물의 배경 역할을 하는 배경사물 1 개 (예: 책상)를 쌍을 이루어 제시하였다. 그림으로 제시되는 대상사물 과 배경사물은 각 문항에서 '위', ‘아래', '앞', ‘뒤’의 공간 관계를 이 루도록 하였다. 단순구성 과제는 네 가지 공간 관계당 3 개 문항으로 총 12 개 문항으로 구성되며 예는 Appendix 1에 제시하였다.

\section{다중구성 과제}

다중구성 과제는 단순구성 과제와 동일하게 친숙화단계, 대비단 계, 검사단계로 구성하였다. 하지만 다중구성 과제는 아동이 검사 단계에서 선택해야 하는 같은 공간 장면이 앞서 제시되는 친숙화단 계와 긍정예시와는 다르게 제시되어 아동이 이해한 새로운 공간명 사의 의미를 다른 사물들의 관계에도 적용할 수 있는 지를 살펴보 았다. 즉, 아동이 새로운 명사 뒤에 위치한 처소격조사 '-에'를 형태 통사적 단서로 활용하여 새로운 명사를 ‘위', '아래’, '앞' '뒤’와 같 이 위치를 나타내는 공간명사로 해석하는지 또는 단순히 배경사물 (예: 의자)로 해석하는지를 새로운 명사의 의미 이해에 초점을 두어 살펴보기 위한 과제이다.

이에 따라 제시되는 장면의 대상사물과 배경사물의 수를 단순 구성 과제와는 다르게 구성하였다. 다중구성 과제에서는 각 문항 에서 대상사물 2개와 배경사물 2개가 각각 쌍을 이루어 '위', '아래', '앞' '뒤'의 공간 관계를 나타낸다. 다중구성 과제 역시 단순구성 과 제와 동일하게 네 가지 공간 관계당 3 개 문항으로 총 12 개 문항으로 구성되며 예는 Appendix 2에 제시하였다.

본 연구의 단순구성 과제와 다중구성 과제에서 공간 관계를 나 타내는 새로운 공간명사는 내용타당도 검증 결과를 바탕으로 Appendix 3과 같이 선정하였다. 새로운 공간명사는 Pae, Kim, Yoon 과 Jang (2015)의 한국어읽기검사(Korean Language-based Reading Assessment, KOLRA)의 해독과제 중 2음절 자소-음소 일치 무 의미 낱말 18 개를 사용하였다. 그리고 KOLRA 해독 과제의 2음절 자소-음소 불일치형 무의미 낱말 중 8 개를 자소-음소 일치형 무의 미 낱말로 수정하여 총 26 개 자소-음소 일치형 무의미 낱말로 새로 운 공간명사를 구성하였다.

\section{타당도}

아동에게 제시하는 단순구성 과제와 다중구성 과제의 그림 자 료와 진행 절차 그리고 새로운 공간명사가 조사 '-에'를 이용한 공 간명사의 이해 능력을 살펴보기 위한 측정치로 적합한지를 검증하 기 위해 3 명의 전문가에게 내용타당도에 관한 평가를 받았다. 3 명 의 전문가는 모두 언어재활사 1 급 자격증과 박사학위 소지자였다. 이들 전문가는 단순구성 과제와 다중구성 과제에 대한 타당도를 Likert 5 점 척도 $(1=$ 매우 부적절, $2=$ 부적절, $3=$ 보통, $4=$ 적절, $5=$ 매우 적절)로 평가하였다. 그 결과 단순구성 과제에서 평균 4.87점, 다중구성 과제에서 평균 4.82점으로 나타났다. 두 과제에서 4점 이 하의 점수를 받은 문항의 그림은 전문가의 의견을 반영하여 그림의 배치나 크기를 수정하였고 이로써 사물들의 공간 관계가 더 명확 하게 가시화될 수 있도록 하였다. 
그리고 새로운 공간명사 중 ‘고드'는 다른 단어가 연상된다는 의 견을 반영하여 ‘소드’로 수정하였다. 또한 ‘박산' '삭눈’과 같이 자소음소 불일치형의 음절구조가 복잡한 명사는 과제를 수행할 때 방 해요소로 작용할 수 있다는 전문가의 의견을 반영하여 '바상' '사 누'와같이자소-음소 일치형 무의미 단어로 수정하여 사용하였다.

\section{연구절차}

본 연구는 검사자가 어린이집과 유치원을 직접 방문하여 실시하 였고 소음의 영향을 최소한으로 받을 수 있는 환경에서 진행하였다. 실험에서 사용한 모든 그림 장면은 책상 위에 놓인 15.6 인치 모니터 로 제시하였다. 검사자는 단순구성 과제를 먼저 시행한 후 다중구 성 과제를 차례대로 실시하였다. 검사자는 단순구성 과제를 시작하 기에 앞서 아동에게 “선생님이 그림을 보여줄 거야. 그리고 처음 듣 는 이상한 말도 들려줄 거야. 이/가 잘 듣고 있다가 나중에 선 생님이 물어보면 두 개 그림 중에서 한 개를 선택해주면 돼."라고 과 제 절차에 대해 설명한 후 연습문항을 먼저 실시하였다. 만약 아동 이 과제 이해에 어려움을 보인다면 위의 과정을 다시 설명해주었다. 그리고 '모르겠어요.'라는 반응 없이, 두 그림 중 하나를 반드시 선택 하도록 과제 수행 방식을 연습한 후 본 문항을 실시하였다. 단순구 성 과제의 문항 12 개를 모두 실시한 후 다중구성 과제를 시행하였 다. 두 과제의 절차는 모두 동일하게 연습문항을 먼저 실시하고 아 동의 이해 여부를 확인한 후, 본 문항 12 개를 실시하였다.

두 가지 과제는 모두 각 문항에서 아동이 문장을 다시 들려 달라 고 요청할 경우 1 회에 한해 한 번 더 들을 수 있는 기회를 제공하였 다. 검사단계에서 검사자의 질문이 제시된 후 10 초 이내에 아동이 반응하지 않을 경우 다음 문항으로 넘어갔다. 모든 아동의 반응은 녹음과 함께 검사를 실시하면서 검사자가 검사 기록지에 기록하였 다(Appendix 4).

\section{자료분석 및 결과처리}

단순구성 과제의 경우 아동이 검사 단계에서 친숙화단계에서 제 시된 공간 장면과 같은 장면을 선택한 경우 정반응으로 1점, 다른 공간 관계를 선택하거나 모르겠다고 반응을 보인 경우는 오반응으 로 0 점을 부여하였고, 모든 문항을 적절하게 선택한 경우 총 12 점을 받도록 하였다.

다중구성 과제에서는 아동이 검사단계에서 친숙화단계와 같은 공간 장면을 선택하거나 친숙화 단계와 같은 배경사물을 선택하는 지를 검사자가 검사지에 기록하였다. 그리고 같은 공간 장면을 선택 한 반응 비율(같은 공간 장면을 선택한 반응수 $/ 12 \times 100)$ 과 같은 배 경사물 장면을 선택한 반응 비율(같은 사물 장면을 선택한 반응수/
$12 \times 100)$ 을 구하였다.

신뢰도

단순구성 과제의 검사단계에서 나타난 정반응 점수와 다중구성 과제의 검사단계에서 같은 공간 관계를 선택한 비율과 같은 사물 을 선택한 비율을 분석한 후 평가자 간 신뢰도를 산출하였다. 평가 자 간 신뢰도는 언어재활사 2 급 자격증을 소지한 1 명의 대학원생에 게 검사의 절차, 기록, 채점 방식을 상세히 설명한 후 전체 수집된 자 료의 $30 \%$ 를 임의로 선정하여 채점하도록 하였다. 그 결과 검사자 간 채점 신뢰도는 $99 \%$ 로 측정되었다.

\section{통계분석}

본 연구에서는 조사 ‘에’를 활용한 형태통사적 단서가 학령전 단 순언어장애 아동의 새로운 공간명사 이해에 미치는 영향을 단순구 성 과제와 다중구성 과제를 통하여 일반아동과 비교하여 살펴보 고자 하였다. 이를 위해 IBM SPSS Statistics version 23 프로그램을 사용하여 독립표본 $t$-검정(two-independent samples $t$-test)을 실시 하였다. 또한 각 집단 내에서 다중구성 과제의 검사단계에서 선택 하는 장면의 비율에 차이가 있는 지를 살펴보기 위해 대응표본 $t$ 검정(two-dependent samples $t$-test)을 실시하였다.

\section{연구결과}

\section{단순언어장애 아동 집단과 일반아동 집단 간 단순구성 과제 수행력}

단순구성 과제에서 두 집단 간 차이를 비교한 결과는 Table 2 와 같다. 이러한 차이가 통계적으로 유의미한지 살펴보기 위해 독립표 본 $t$-검정을 실시한 결과, 두 집단 간 정반응 점수에 유의미한 차이 가 없는 것으로 나타났다.

\section{단순언어장애 아동 집단과 일반아동 집단 간 다중구성 과제 수행력}

단순언어장애 아동 집단과 일반아동 집단 간 다중구성 과제의

Table 2. Correct response score on simple composition task among the two groups

\begin{tabular}{lccc}
\hline & SLI group & TD group & $t$ \\
\hline Correct response score & $9.87(1.69)$ & $10.73(1.28)$ & -1.587 \\
\hline
\end{tabular}

Values are presented as mean (SD).

$\mathrm{SLI}=$ children with specific language impairment; $\mathrm{TD}=$ children with typically developing. 
Table 3. rate of selected scenes on multiple composition task among the two groups

\begin{tabular}{|c|c|c|c|c|c|}
\hline & \multicolumn{2}{|c|}{ SLI } & \multicolumn{2}{|c|}{ TD } & \multirow{2}{*}{$t$} \\
\hline & M & SD & M & SD & \\
\hline Same spatial relation scene & 61.66 & 18.31 & 83.89 & 11.12 & $-4.021^{*}$ \\
\hline Same background objects scene & 38.34 & 18.31 & 16.11 & 11.12 & $4.021^{*}$ \\
\hline
\end{tabular}

Values are presented as mean (SD).

$\mathrm{SLI}=$ children with specific language impairment; $\mathrm{TD}$ = children with typically developing.

${ }^{*} p<.05$.

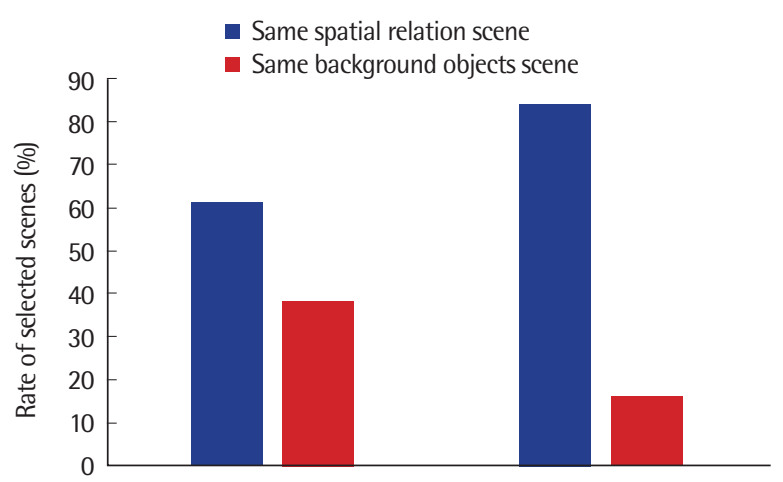

SLI

TD

Figure 1. Rate of selected scenes on multiple composition task among the two groups.

$S L I=$ children with specific language impairment; $T D=$ children with typically developing.

검사단계에서 친숙화단계와 같은 공간 관계 장면을 선택한 비율에 대한 독립표본 $t$-검정 결과는 Table 3 과 같다. 다중구성 과제의 검 사단계에서 친숙화단계와 같은 공간 관계 장면을 선택한 비율과 같 은 배경사물 장면을 선택한 비율에 대한 독립표본 $t$-검정 결과는 Table 3과 Figure 1에 제시하였다.

두 집단 간 차이를 비교한 결과, 단순언어장애 아동 집단이 다중 구성 과제의 검사단계에서 친숙화단계와 같은 공간 관계 장면을 선 택한 비율은 일반아동 집단 보다 낮게 나타났다. 그리고 단순언어 장애 아동이 친숙화단계와 같은 배경사물 선택 장면을 선택한 비 율은 일반아동 집단 보다 높게 나타났다. 집단 간 통계적으로 유의 미한 차이가 있는지 살펴보기 위해 독립표본 $t$-검정을 실시한 결과, 같은 공간 관계 장면을 선택한 비율 $(t=-4.021, p<.05)$ 과 같은 배경 사물 장면을 선택한 비율 $(t=4.021, p<.05)$ 모두 유의미한 차이가 있는 것으로 나타났다.

\section{단순언어장애 아동 집단과 일반아동 집단 내 다중구성 과제 수행력}

단순언어장애 아동과 일반아동의 각 집단 내에서 다중구성 과
Table 4. Rate of selected scenes on multiple composition task in each group

\begin{tabular}{lccc}
\hline & $\begin{array}{c}\text { Same spatial } \\
\text { relation scene }\end{array}$ & $\begin{array}{c}\text { Same background } \\
\text { objects scene }\end{array}$ & $t$ \\
\hline SLI group & $61.66(18.31)$ & $38.34(18.31)$ & $2.467^{*}$ \\
TD group & $83.89(11.12)$ & $16.11(11.12)$ & $11.808^{*}$ \\
\hline
\end{tabular}

Values are presented as mean (SD).

$S L I=$ children with specific language impairment; $T D=$ children with typically developing.

${ }^{*} p<.05$.

제에서 선택하는 장면의 비율에 차이가 있는 지를 살펴보기 위한 대응표본 $t$-검정에 대한 결과는 Table 4 에 제시하였다.

단순언어장애 아동 집단의 다중구성 과제에서 선택한 장면의 비 율에 차이가 있는지 살펴본 결과 같은 공간 관계 장면을 선택한 비 율이 같은 배경사물 장면 보다 높은 것으로 나타났다. 이러한 차이 가 통계적으로 유의미한지 살펴보기 위해 대응표본 $t$-검정을 실시 한 결과, 유의미한 차이가 있는 것으로 나타났다 $(t=2.467, p<.05)$. 또한, 일반아동 집단이 다중구성 과제에서 선택한 장면의 비율에 차이가 있는지 살펴본 결과 같은 공간 관계 장면을 선택한 장면의 비율이 같은 배경사물 장면을 선택한 비율보다 높은 것으로 나타 났다. 이러한 차이가 통계적으로 유의미한지 살펴보기 위해 대응표 본 $t$-검정을 실시한 결과, 유의미한 차이가 있는 것으로 나타났다 $(t=11.808, p<.05)$.

\section{논의 및 결론}

본 연구에서는 학령전 단순언어장애 아동이 새로운 명사가 제시 되었을 때, 형태통사적 단서인 처소격조사 '-에'를 활용하여 이 새 로운 명사를 ‘위', ‘아래’, '앞', ‘뒤'와 같은 공간명사로 이해할 수 있 는 지를 단순구성 과제와 다중구성 과제를 이용하여 일반아동의 수행과 비교해 살펴보고자하였다.

단순구성 과제에서 두 집단 아동들이 적절한 공간 관계 장면을 선택한 정반응 점수의 차이를 살펴본 결과, 단순언어장애 아동과 일반아동 집단 간 정반응 점수에서는 통계적으로 유의미한 차이가 나타나지 않았다. 다시 말해, 문항당 한 가지 대상사물과 한 가지 배 경사물로 공간 장면을 구성한 단순구성 과제를 두 집단에게 시행 하였을 때 단순언어장애 아동 집단도 일반아동 집단과 마찬가지로 적절한 공간 관계 장면을 선택할 수 있었다. 이와 같은 결과는 단순 언어장애 아동이 한 가지 대상사물이 배경사물로 단순하게 구성된 장면에 반복적으로 노출되었을 때에는 일반아동과 마찬가지로 처 소격조사 '-에’를 형태통사적 단서로 활용하여 새로운 낱말의 의미 를 공간명사로 이해할 수 있었다고 해석할 수 있다. 
하지만, 한 문항당 두 가지 대상사물과 두 가지 배경사물로 구성 된 다중구성 과제에서 단순언어장애 아동 집단과 일반아동 집단 간 선택한 장면의 비율로 수행 차이를 살펴본 결과에서는, 단순언 어장애 아동 집단이 일반아동 집단보다 검사 단계에서 친숙화 단 계와 동일한 공간 관계 장면을 선택한 비율이 낮았고, 그 차이는 통 계적으로 유의미하였다. 그리고 다중구성 과제에서 선택한 장면의 비율의 차이를 두 집단 내에서 살펴본 결과, 단순언어장애 아동과 일반아동 집단 아동 모두 친숙화단계와 동일한 공간 관계 장면을 선택한 비율이 높았고 이러한 차이 역시 통계적으로 유의미하였다.

즉 두 집단 아동 모두 다중구성 과제에서 새로운 명사를 배경사 물로 이해하기 보다는 공간명사로 이해하여 같은 공간 관계 장면을 선택하는 비율이 높았다. 하지만 집단 간 다중구성 과제에서 같은 공간 관계 장면을 선택한 비율에서는 단순언어장애 아동 보다 일 반아동이 유의미하게 높게 나타났다. 이러한 결과는 단순언어장애 아동도 일반 아동과 마찬가지로 빠른연결하기와 형태통사적 자동 처리를 통해 새로운 명사를 공간명사로 해석하기는 하지만, 한 문 항에서 제시되는 사물의 수가 4 개인 다중구성 과제에서는 비일관 적으로 발휘되고 있다고 설명할 수 있다.

본 연구의 단순구성 과제는 친숙화단계와 대비단계의 긍정예시 에서 이미 보았던 것과 동일한 그림 장면이 마지막 검사단계에 제시 된다. 따라서 대상 아동들에게 단순구성 과제는 앞선 단계에서 보 았던 것과 동일한 장면이 제시되지 않는 다중구성 과제보다는 비 교적 쉬운 난이도의 과제이다. 이처럼 이미 보았던 장면이 반복되 고 제시되는 사물의 수가 2 개인 단순구성 과제에서는 단순언어장 애 아동도 빠른 연결하기와 처소격조사 '-에’를 활용한 형태통사적 자동처리를 통해 새로운 공간명사의 의미를 추론하여 정반응을 보 일 수 있었다. 하지만 제시되는 사물의 수를 4 개로 구성하여 처음 연결한 의미를 다른 사물들의 공간 관계에까지 적용시켜야 하는 다중구성 과제에서는 단순언어장애 아동이 일반아동보다 새로운 명사를 공간명사로 이해하는데 어려움을 보였다.

Dollaghan (1987)은 일반아동과 단순언어장애 아동의 빠른연결 능력을 비교하기 위하여 /koob/이라는 무의미 단어를 사용하여 수 행을 비교하였다. 그 결과 새로운 단어를 1 회 노출한 후, 새로운 단 어의 이해 및 대상물의 비언어적 정보를 회상하는 것에 있어서는 일반아동과 단순언어장애 아동에서는 차이가 없었다고 한다. 하지 만 Rice, Buhr와 Nemeth (1990)는 5세 단순언어장애 아동과 일반 아동의 빠른연결 능력을 비디오를 시청하게 하여 새로운 단어를 제 시하여 살펴보았다. 연구 결과, 단순언어장애 아동이 일반아동에 비해 새로운 단어를 이해하는 데 어려움을 나타내었다. 이러한 연 구결과는 Dollaghan (1987)이 단순언어장애 아동이 정상 아동과
비교해 새로운 명사를 학습하는 능력이 유사하다고 한 것과 차이 를 나타낸다. 그러나 이러한 차이점을 Rice 등(1990)은 Dollaghan (1987)이 실시한 연구 과제가 단순언어장애 아동도 수행하기에 비 교적 쉬운 과제였기 때문이라고 보았다. 또한 Rice 등(1994)은 단순 언어언어장애 아동의 단어 습득의 결함이 이들이 동일한 연령의 일반아동보다 문법적 단서를 단어 의미 습득에 유용한 책략으로 사용하지 못하기 때문이라고 지적하였다. 이렇듯, 본 연구의 다중 구성 과제에서 단순언어장애 아동 집단이 새로운 명사의 의미를 적절한 공간명사로 해석할 수 있었던 비율이 일반아동 집단보다 유 의미하게 낮았던 것은 비교적 복잡한 과제에서 문법적 단서를 활용 하여 빠른연결하기 책략을 원활하게 사용하는 데 어려움이 있었다 는 것으로 설명할 수 있다.

단순언어장애 아동 집단이 같은 공간 관계 장면을 선택한 비율 이 일반아동보다 낮았던 결과는 단순언어장애 아동 집단이 일반 아동 집단보다 조사 '-에'를 단서로 하여 새로운 명사의 의미를 공 간명사로 해석하는 데 어려움을 보인다는 것으로 해석할 수 있다. 단순언어장애 아동 집단이 조사 '-에’를 형태통사적 단서로 활용하 여 새로운 명사의 의미를 ‘위', '아래', '앞', ‘뒤'와 같은 공간명사로 해 석하는 데 일반아동보다 어려움을 보인 것은 이들의 형태통사적 자동처리 과정에서의 어려움과 관련 지을 수 있을 것이다.

한국어의 문법형태소 습득에 관한 초기 연구에서는 일반아동 들은 대체로 2 세경부터 문법형태소를 습득하며, 가장 먼저 출현하 는 부사격조사는 처소격조사 ‘-에’라고 밝혔다(Zoh, 1982). 아동은 어휘 습득 초기에 자신이 이미 알고 있는 처소격조사 '-에'와 같은 형태통사적 정보들을 활용하여 새로운 어휘의 의미를 자동처리를 통해 습득한다. Lee와 Song (2009)의 연구에서는 만 2세 5개월의 한국아동들이 새로운 동사의 의미를 이해를 하는 과정에서 주격 또는 목적격조사와 같은 문법형태소 정보를 활용할 수 있음을 밝 혔다. 그리고 Lee와 Song (2010a)의 연구에서도 역시 만 3-4세의 한 국아동들이 주격조사와 처소격조사 앞에 위치한 새로운 명사의 의미를 각각 다르게 해석할 수 있음을 보여주었다. 이러한 선행연 구는 적어도 만 4 세의 일반아동은 새로운 어휘가 포함된 문장을 이해할 때 문법형태소를 중요한 단서로 활용한다는 형태통사적 자 동처리 가설을 뒷받침하고 있다(Göksun et al., 2008).

본 연구의 결과를 종합해 본다면, 학령전 시기 일반아동은 빠른 연결하기와 형태통사적 자동처리 능력을 바탕으로 두 과제에서 처 소격조사 '-에' 앞에 위치한 새로운 공간명사를 적절하게 습득할 수 있었다. 단순언어장애 아동의 경우 새로운 공간명사의 출현 장 면이 단순하게 구성되고 같은 장면이 반복적으로 노출되는 단순구 성 과제에서는 일반아동과 수행력의 차이를 보이지 않았다. 하지만 
다중구성 과제와 같이 처음 이해한 새로운 어휘의 의미를 다른 사 물들의 공간 관계에 적용할 수 있어야 하는 복잡한 과제에서는 이 러한 어휘 습득 전략을 사용함에 있어 일반아동보다 어려움을 보 였다. 단순언어장애 아동의 이러한 어려움은 빠른연결하기와 형태 통사적 자동처리의 제한으로 볼 수 있다.

본 연구에서 조사'에'를 활용한 형태통사적 단서가 학령전 단순 언어장애 아동의 공간명사 이해에 미치는 영향을 일반아동과 비교 해 본 결과를 토대로 다음과 같이 임상적 시사점을 정리할 수 있다. 첫째, 단순언어장애 아동은 조사 ‘-에' 앞에 위치한 새로운 공간명 사가 포함된 문장을 이해하는 과정에서 일반아동보다 낮은 수행력 을 보였다. 이와 같은 본 연구의 결과는 단순언어장애 아동이 일반 아동보다 새로운 공간명사를 습득하는 데 있어서 조사 '-에'와 '에 있어.와 같은 문장의 구조를 활용하는 것에 어려움이 있다고 해석 할 수 있다. 따라서 단순언어장애 아동의 효과적인 어휘중재를 위 해서는 단순히 단어 의미에 초점을 둔 중재기법의 적용을 넘어, 문 법형태소와 더불어 문장구조와 같은 형태통사론적 측면의 중재가 함께 이루어져야 함을 시사한다. 둘째, 본 연구의 단순구성 과제에 서 두 집단 간 정반응 점수에는 유의미한 차이가 없었다.

이러한 결과는 단순언어장애 아동이 공간 개념이라는 추상적인 개념을 바탕으로 하는 공간명사를 습득할 때, 제시되는 대상사물 과 배경사물이 중요한 단서로서 역할을 하기도 하지만, 오히려 많 은 방해요인으로 작용할 수 있다는 것을 의미한다. 즉, 새로운 공간 명사를 습득할 때 함께 제시되는 대상사물과 배경사물의 수가 많 을수록 아동이 공간명사의 의미를 정확하게 파악하는 데 어려움 을 초래할 수 있다. 따라서 공간명사를 중재하는 과정에서 대상사 물과 배경사물을 단순화하는 것이 단순언어장애 아동이 빠른연결 하기와 형태통사적 자동처리와 같은 어휘 습득 전략을 원활하게 사용할 수 있도록 하는 지도 전략이 될 수 있다.

본 연구의 두 가지 과제는 검사단계에서 두 장면이 제시되었고 검사자의 물음에 아동이 두 장면 중 한 장면을 선택하는 응답방식 으로 과제가 진행되었다. 그렇기 때문에 검사단계에서 아동의 무작 위 반응이 연구결과에 영향을 미쳤을 가능성을 완전히 배제하기 는 어렵다. 따라서 후속 연구에서는 검사단계에서 전혀 다른 공간 관계를 이루고 있는 오답 장면을 추가로 구성하여 아동이 세 가지 장면 중 한 가지 장면을 선택하는 응답방식으로 과제를 재구성하 여 살펴볼 필요가 있을 것이다.

그리고 아동이 단순구성 과제를 수행하는 과정에서 대상사물과 배경사물의 공간 관계를 고려하여 새로운 공간명사의 의미를 추론 하지 않더라도 검사단계에서 정반응할 수 있었다. 아동이 검사단계 바로 직전에 제시되는 긍정예시의 그림 장면과 자극 문장을 짝지어
기억한다면, 바로 뒤에 이어지는 검사단계에서 같은 그림을 고르면 되는 것이기 때문이다. 이러한 방법으로 단순구성 과제를 해결했다 면, 아동이 새로운 명사의 의미를 공간명사로 해석하지 않더라도 검사단계에서 이전 단계와 똑같은 그림 장면을 선택함으로써 정반 응으로 기록이 될 수 있었다. 따라서 후속 연구에서 대비단계의 부 정예시와 긍정예시 다음에 다른 공간 관계를 나타내는 부정예시 장면을 추가로 구성한다면, 이후 이어질 검사단계에서 이전 장면과 똑같은 장면이 답이 되지 않기 때문에 본 연구의 한계를 개선하는 과제 구성이 될 수 있을 것이다.

마지막으로 본 연구에서 제시되는 새로운 공간명사는 ‘위', ‘아 래', '앞' '뒤'와 같이 발달 초기에 습득되는 쉬운 공간명사의 의미를 담고 있었다. 이후 연구에서 '옆, '안', '밖’과 같은 공간명사의 습득 과정을 살펴보거나, 더 나아가 '오다', '나오다', '가다'와 같은 공간 동사의 습득 양상을 살펴본다면 아동의 언어와 인지 발달의 관련 성을 밝히는 가치 있는 연구가 될 것이다.

\section{REFERENCES}

Carey, S. (2010). Beyond fast mapping. Language Learning and Development, 6(3), 184-205.

Clark, E. (1980). Convention and innovation in acquiring the lexicon. Papers and Reports on Child Language Development, 19, 1-20.

Clark, E. V. (1973). What's in a word? On the child's acquisition of semantics in his first language. In T. E. Moore (Ed.), Cognitive development and acquisition of language (pp. 65-110). New York, NY: Academic Press.

Dollaghan, C. A. (1987). Fast mapping in normal and language-impaired children. Journal of Speech and Hearing Disorders, 52(3), 218-222.

Ellis Weismer, S., \& Hesketh, L. J. (1998). The impact of emphatic stress on novel word learning by children with specific language impairment. Journal of Speech, Language, and Hearing Research, 41(6), 1444-1458.

Fisher, C. (2002). Structural limits on verb mapping: the role of abstract structure in 2.5-year-olds' interpretations of novel verbs. Developmental Science, 5(1), 55-64.

Göksun, T., Küntay, A. C., \& Naigles, L. R. (2008). Turkish children use morphosyntactic bootstrapping in interpreting verb meaning. Journal of Child Language, 35(2), 291-323.

Gray, S. (2003). Word-learning by preschoolers with specific language impairment. Journal of Speech, Language, and Hearing Research, 46(1), 56-67.

Grela, B., Rashiti, L., \& Soares, M. (2004). Dative prepositions in children with specific language impairment. Applied Psycholinguistics, 25(4), 467-480. 
Sungyi Choi, et al. • Comprehension of spatial nouns Using a Locative Case Marker

Hoff, E. (2009). Language development (4th ed.). Belmont, CA: Cengage Learning.

Kim, H. S., Jang, M. S., \& Kim, S. S. (2011). Syntactic processing ability of children with specific language impairment. Journal of Special Education: Theory and Practice, 12(4), 93-111.

Kim, Y. T., Sung, T. J., \& Lee, Y. K. (2003). Preschool receptive-expressive language scale (PRES). Seoul: Seoul Community Rehabilitation Center.

Korea Institute for Research in the Behavioral Sciences. (1980). Longitudinal Study of Korean Children: 6th Research Result. Seoul: Author.

Lee, S. (1990). A study on the word of space concept development of infants (Master's thesis). Kookmin University, Seoul, Korea.

Lee, S., \& Lee, H. (2012). The astonishing language development of children. Seoul: Hakjisa.

Lee, W. Y., \& Song, H. J. (2009). Two-year-old children use morphological cues to learn verb meanings. Korean Journal of Developmental Psychology, 22(4), 111-123.

Lee, Y. H., \& Song, H. J. (2010a). Korean children use case markers to learn the meanings of novel nouns. Korean Journal of Developmental Psychology, 23(1), 103-117.

Lee, Y. H., \& Song, H. J. (2010b). Korean children and adults use a locative case marker to infer the meaning of novel spatial nouns. Korean Journal of Developmental Psychology, 23(4), 17-31.

Leonard, L. B. (2014). Children with specific language impairment (2nd ed.). Cambridge, MA: MIT Press.

Min, H. S. (1999). Korean Grammar Study. Seoul: Youkrack.

Nash, M., \& Donaldson, M. L. (2005). Word learning in children with vocabulary deficits. Journal of Speech, Language, and Hearing Research, 48(2), 439-458.
Owens, R. E. (2012). Language development: an introduction (8th ed.). Boston, MA: Pearson.

Pae, S., Kim, M., Yoon, H. J., \& Jang, S. (2015). Korean Language Based Reading Assessment (KOLRA). Seoul: Hakjisa.

Park, H., Kwak, K., \& Park, K. (1997). Korean-Wechsler Preschool and Primary Scale of Intelligence (K-WPPSI). Seoul: Seoul Community Rehabilitation Center.

Quinn, P. C. (2005). Developmental constraints on the representation of spatial relation information: evidence from preverbal infants. In L. A. Carlson \& E. van der Zee (Eds.), Functional features in language and space: insights from perception, categorization, and development (pp. 293-309). Oxford, UK: Oxford University Press.

Rice, M. L., Buhr, J. C., \& Nemeth, M. (1990). Fast mapping word-learning abilities of language-delayed preschoolers. Journal of Speech and Hearing Disorders, 55(1), 33-42.

Rice, M. L., Oetting, J. B., Marquis, J., Bode, J., \& Pae, S. (1994). Frequency of input effects on word comprehension of children with specific language impairment. Journal of Speech, Language, and Hearing Research, 37(1), 106-122.

Yi, S. H. (2000). The acquisition of Korean grammatical morphemes in early childhood. Korean Journal of Child Studies, 21(4), 51-68.

Yoon, Y. (1985). Study on the development of orientation concepts in the young children (Master's thesis). Ewha Womans University, Seoul, Korea.

Zlatev, J. (2010). Spatial semantics. In D. Geeraerts \& H. Cuyckens (Eds.), The Oxford handbook of cognitive linguistics (pp. 318-350). New York, NY: Oxford University Press.

Zoh, M. H. (1982). A study on language acquisition of Korean children: strategy model. Seoul: Seoul National University Press. 
Appendix 1. Simple composition task

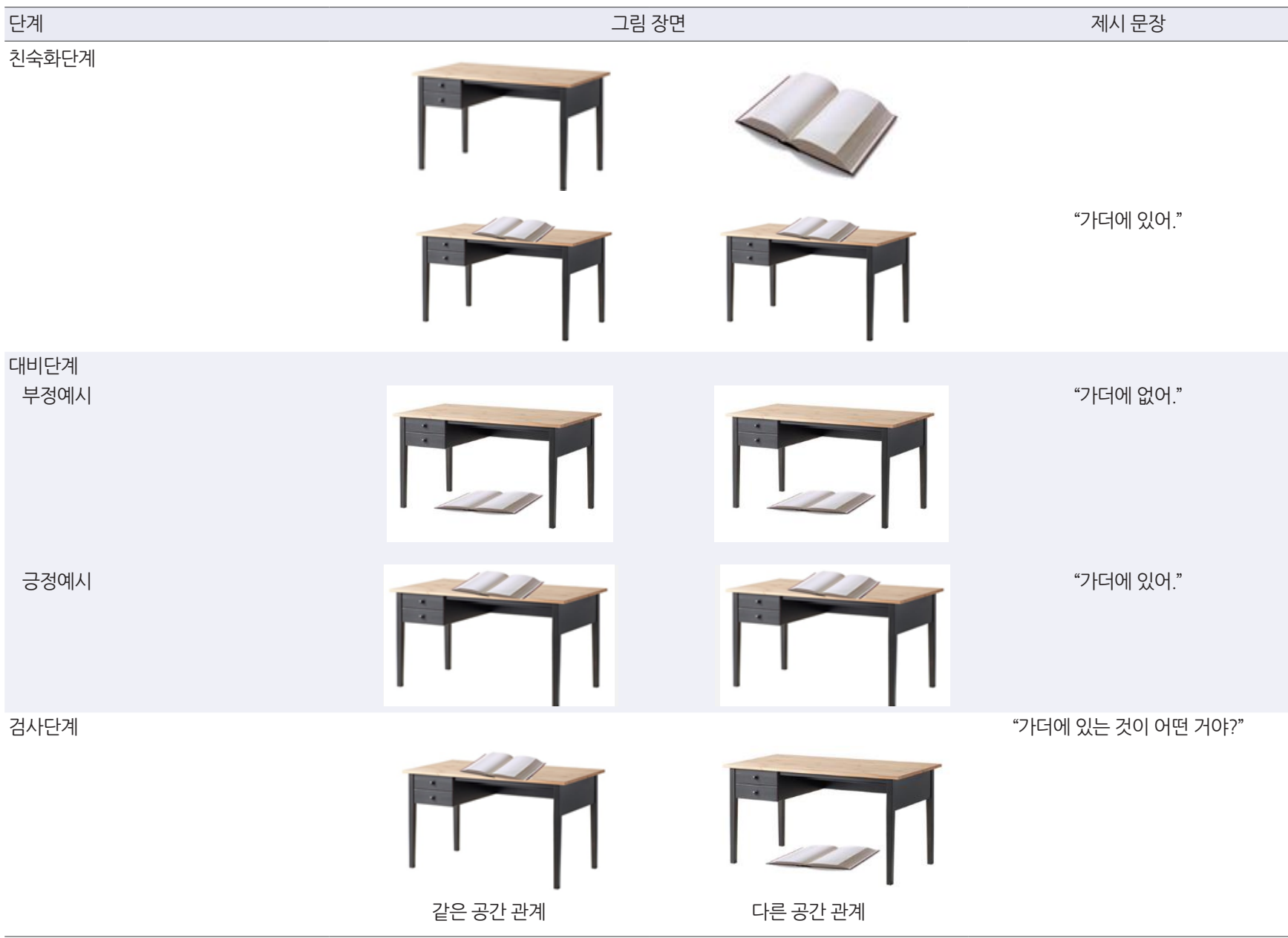


Appendix 2. Multiple composition task

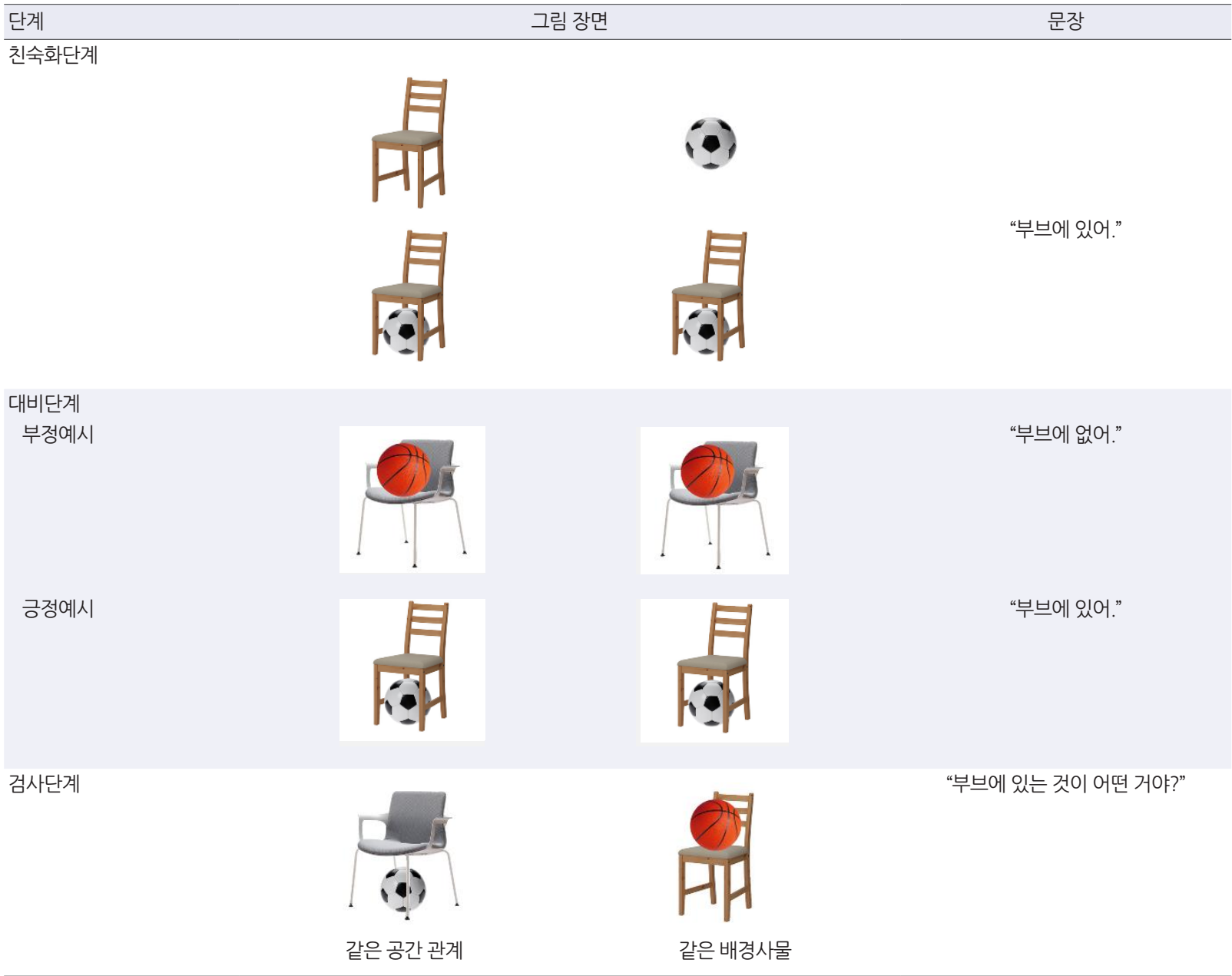

Appendix 3. List of spatial nouns used in tasks

\begin{tabular}{lccc}
\hline & & 공간 관계 & 새로운 공간명사 \\
\hline 단순구성 과제 & (연습문항) & 앞 & 수우 \\
& & 위 & 가더, 바상, 찌배 \\
& 아래 & 시지, 사누, 소드 \\
& 앞 & 수젤, 벙미, 조번 \\
& 뒤 & 둔촐, 보티, 솔문 \\
다중구성 과제 & (연습문항) & 아래 & 간시 \\
& & 위 & 점총, 말내, 달만 \\
& 아래 & 부브, 비줄, 유소 \\
& 앞 & 동도, 다돈, 터니 \\
& 뒤 & 분달, 해치, 판두 \\
\hline
\end{tabular}


Appendix 4. 검사 기록지

\begin{tabular}{|c|c|c|ccc|}
\hline 아동명 & 생년월일 & 년 & 월 & 일 $($; $)$ \\
\hline 성 별 & 검 사 일 & & & \\
\hline 검사자 & \multicolumn{4}{|c|}{} \\
\hline
\end{tabular}

\section{1. 단순구성과제}

아동이 검사 단계에서 선택한 장면의 번호를 $\bigcirc$ 하세요.

\begin{tabular}{|l|c|c|c|}
\hline \multicolumn{1}{|c|}{ 문항 번호 } & 선택한 장면 & 문항 번호 & 선택한 장면 \\
\hline 연습문항) 수우 & $1 / 2$ & 7) 보티 & $1 / \underline{2}$ \\
\hline 1) 가더 & $1 / 2$ & 8) 벙미 & $1 / \underline{2}$ \\
\hline 2) 수젤 & $1 / 2$ & 9) 솔문 & $1 / \underline{2}$ \\
\hline 3) 시지 & $1 / 2$ & $10)$ 조번 & $1 / 2$ \\
\hline 4) 둔촐 & $1 / 2$ & 11) 찌배 & $1 / 2$ \\
\hline 5) 바상 & $1 / 2$ & 12) 소드 & $1 / 2$ \\
\hline 6) 사누 & $1 / 2$ & & 합계 점 \\
\hline
\end{tabular}

\section{2. 다중구성과제}

아동이 검사 단계에서 선택한 장면의 번호를 $\bigcirc$ 하세요.

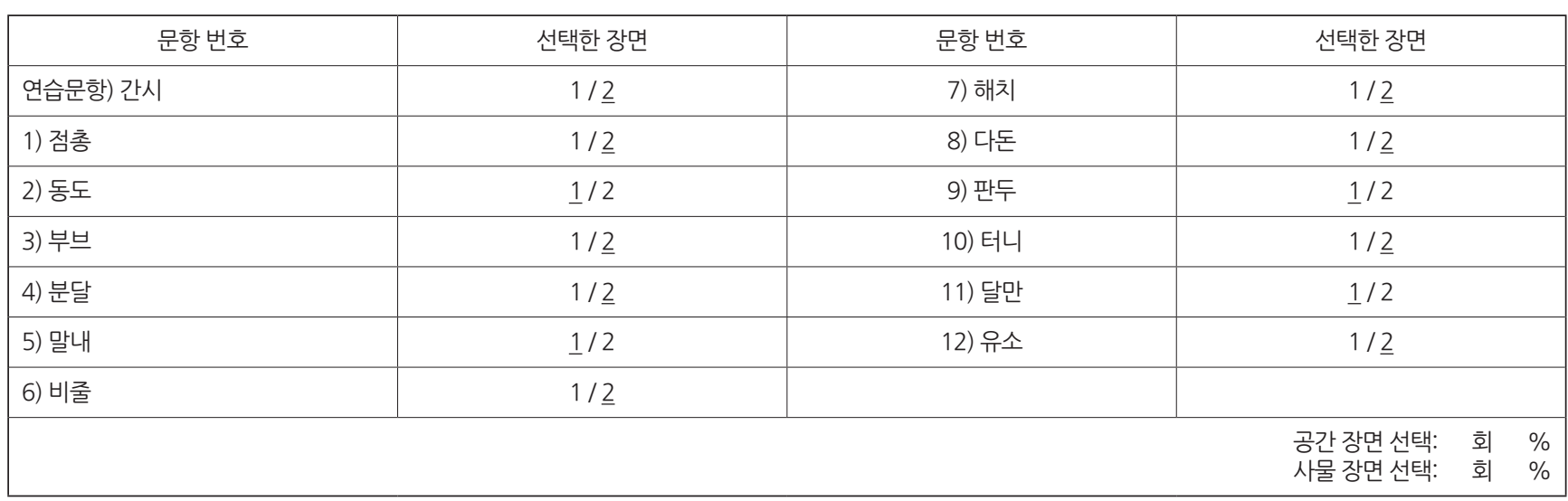




\section{국문초록}

\section{학령전 단순언어장애 아동의 조사 '-에’를 활용한 공간명사의 이해}

최성이 ${ }^{1} \cdot$ 이희란

1부산가톨릭대학교 대학원 언어청각치료학과, ${ }^{2}$ 부산가톨릭대학교 언어청각치료학과

배경 및 목적: 본 연구는 단순언어장애 아동과 일반아동을 대상으로 조사 ‘-에'를 형태통사적 단서로 활용하여 새로운 공간명사 이해 하는 특성을 살펴보고자 하였다. 방법: 연구대상은 만 5-6세 단순언어장애 아동 15 명과 생활연령을 일치시킨 일반아동 15 명으로 총 30 명이었다. 이들을 대상으로 조사 '-에’를 활용한 공간명사 이해능력을 단순구성 과제와 다중구성 과제를 통해 살펴보았다. 결과: 두 유 형의 과제를 통해 수행력을 분석한 결과, 단순구성 과제에서는 단순언어장애 아동 집단도 일반아동 집단과 마찬가지로 적절할 공간 관 계 장면을 선택할 수 있었다. 하지만 다중구성 과제에서는 단순언어장애 아동 집단이 일반아동 집단보다 낮은 수행력을 보이는 것으로 나타났다. 논의 및 결론: 단순언어장애 아동 집단은 일반아동 집단보다 제시되는 사물의 수가 많아 복잡한 다중구성 과제에서 조사 ‘-에’를 단서로 새로운 명사의 의미를 ‘위', '아래’, '앞' '뒤’와 같은 공간명사로 해석하는 데 어려움을 보였다. 본 연구에서는 단순언어장 애 아동의 공간명사 이해의 어려움을 빠른연결하기의 제한과 형태통사적 자동처리의 어려움 그리고 관련 요인들을 연결 지어 해석하였 다. 그리고 본 연구의 결과를 통해 단순언어장애 아동의 효과적인 어휘중재를 위해서는 어휘의 의미에 초점을 둔 중재와 더불어 문법형 태소, 문장구조와 같은 형태통사론적 측면의 중재가 필요하다는 것을 논의하였다.

핵심어: 공간명사, 단순언어장애, 형태통사적 자동처리

\section{참고문헌}

김영태, 성태제, 이윤경(2003). 취학전 아동의 수용언어 및 표현언어 척도(PRES). 서울: 서울장애인종합복지관. 김화수, 장만순, 김성수(2011). 단순언어장애 아동의 통사처리능력. 특수교육저널: 이론과 실천, 12(4), 93-111. 민현식(1999). 국어 문법 연구. 서울: 역락.

박혜원, 곽금주, 박광배(1997). 한국-웩슬러 유아지능검사(K-WPPSI). 서울: 도서출판 특수교육. 배소영, 김미배, 윤효진, 장승민(2015). 한국어 읽기검사(KOLRA). 서울: 학지사. 윤경숙(1985). 유아의 방향개념 발달에 관한 연구. 이화여자대학교 대학원 석사학위논문. 이성자(1990). 유아의 위치 공간개념어 발달에 관한 연구. 국민대학교 대학원 석사학위논문. 이순형(2000). 한국아동이 초기에 획득한 문법적 형태소의 종류 및 획득 시기. 아동학회지, 21(4), 51-68. 이승복, 이희란(2012). 아이와 함께하는 신기한 언어발달: 아이의 말과 언어발달 과정의 관찰 기록. 서울: 학지사. 이우열, 송현주(2009). 형태론적 단서가 만 2세 아동의 새로운 동사학습에 미치는 영향. 한국심리학회지: 발달, 22(4), 111-123. 이윤하, 송현주(2010a). 한국 아동의 조사를 이용한 새로운 명사 학습. 한국심리학회지: 발달, 23(1), 103-117. 이윤하, 송현주(2010b). 한국 아동과 성인의 처소격 조사를 활용한 공간 명사의 의미 이해. 한국심리학회지: 발달, 23(4), 17-31. 조명한(1982). 한국아동의 언어획득 연구: 책략모형. 서울: 서울대학교출판부. 한국행동과학연구소(1980). 한국아동의 종단적 연구: 제6차 연구결과. 서울: 한국행동과학연구소.

\section{ORCID}

최성이(제1저자, https://orcid.org/0000-0001-5130-6833); 이희란(교신저자, https://orcid.org/0000-0002-7898-4623) 